\title{
The Scholarship of Teaching: A Canadian Perspective with Examples
}

\section{JOE CUNSOLO, MEI-FEI ELRICK, ALEX MIDDLETON}

University of Guelph

\author{
DALE ROY \\ McMaster University
}

\begin{abstract}
Scholarship is the heart of academic work. Recognizing this the Carnegie report (Boyer, 1990) urges universities to extend the definition of scholarship to include application, teaching, and integration, as well as discovery, thereby making it possible to value all academic work. Although this inclusive view of scholarship holds promise, questions remain concerning the scholarship of teaching and how such scholarship differs from the activities which presently comprise teaching. How would scholarship be identified with teaching, enhance practices, and foster the development of teaching? These questions are addressed, examples given of teaching scholarship, and of institutional policies which support it. The enhancement of teaching, as it meets scholarship's criteria, is discussed.
\end{abstract}




\section{Résumé}

Les activités savantes sont au coeur du travail universitaire. Conscient de cette réalité, le rapport Carnegie (Boyer, 1990) incite les universités à définir l'activité savante de façon à y inclure la pratique de l'enseignement, son intégration et ses découvertes-ce qui permettrait de valoriser toutes les facettes du travail universitaire. Bien que cette définition élargie de l'activité savante soit prometteuse, il faut se poser de nombreuses questions sur "l'enseignement comme activité savante" et sur la façon dont cette activité savante se distingue des activités dont l'enseignement est présentement constitué. Comment peut-on incorporer la notion d'activité savante à l'enseignement, et dans quelle mesure viendrait-elle à la fois perfectionner les méthodes pédagogiques et favoriser l'essor de l'enseignement? Cet article se penche non seulement sur ces questions, mais aussi sur des exemples de l'enseignement comme activité savante et sur des politiques institutionnelles qui en font la promotion. Enfin, l'article discute du perfectionnement de l'enseignement au fur et à mesure que celui-ci répond aux normes de ce qu'est l'activité savante.

[We must] ". . . know when an idea ... extends the definition of the university and makes it more viable."

- Warren Bennis •

As calls for reform in undergraduate education become ever more insistent (AAC, 1985; Bok, 1992; Smith, 1991), the argument for a new vision of scholarship holds great promise. In Scholarship Reconsidered, Boyer (1990) urges the university to include application, integration, and teaching, as well as discovery, in its definition of scholarship because "...knowledge is acquired through research, through synthesis, through practice, and through teaching" (p. 13). Scholarship's centrality in the university, he reasons, will make it possible for all academic work to be valued and rewarded. Now the overwhelming emphasis on discipline research means that academics who wish to apply, teach, or integrate knowledge find their contributions receive little collegial approval and few rewards (Fairweather, 1993; Skolnik \& Rowan, 1984). 
There are further advantages to reconsidering scholarship which arises from the new opportunities to explore multiple ways of knowing: abstract-concrete and reflective-active (Rice, 1992). The creative tension generated as academics examine knowledge from these many perspectives enables them to fully explore their disciplines.

As academics and academic administrators examine Boyer's (1990) report, however, questions surface. What does he actually mean when he talks of the scholarship of teaching? Does he assume all teaching activities are a form of scholarship? Then will teaching become scholarship simply by calling it scholarship? Does he assume new words for describing teaching will make it possible to recognize and reward it?

Or if, as Cerbin (1993) argues, all teaching in higher education is not scholarship, what teaching constitutes scholarly work? All faculty members know they teach. They wonder what more they would do if they engaged in the scholarship of teaching. 'Would they teach more than their colleagues who teach and also conduct discipline research? But if the scholarship of teaching is equated with quantity, does that assume there is a scholarly component in all teaching? If so, that would mean those teaching more could be rewarded.

Then there is the question of how the scholarship of teaching might silence higher education's critics. Bok (1992), for example, thinks teaching is "...one of the few human activities that does not get demonstrably better from one generation to the next" (p. 18).

We will consider the various arguments and queries raised in Scholarship Reconsidered (Boyer, 1990) by addressing three fundamental questions: What is scholarship? What is the scholarship of teaching? How would the scholarship of teaching lead to the development of teaching and its advancement? To expand on the responses to these questions we will give Canadian examples of the scholarship of teaching and institutional policies which support scholarly diversity. These instances are critical because, as Schön (1990) notes, without examples it is difficult to know what someone means. 


\section{Scholarship: Criteria and Characteristics}

If teaching is to be scholarly, it must meet the same standards as all scholarship. Lynton (1993) suggests scholarship has three characteristics and criteria:

1. Scholarship is a reasoned and reflective process in which the scholar makes a number of deliberate choices as to objectives and methods for achieving them, adapting these as the process evolves.

2. The scholar always strives to acquire new, generalized knowledge from the specific activity.

3. Scholarship is communicated to others. He thinks the "...individual has an obligation to share such newly acquired insights with colleagues."

Braxton (1991) believes scholarship is characterized by skepticism no knowledge claim or research findings should be accepted without empirical or logical criteria. He, too, thinks scholarship's results belong to the academic community and, hence, peers must be aware of the findings.

Time is not included in the above criteria. Just as no one argues that spending time in the laboratory, archives, or field automatically produces the scholarship of discovery, academics cannot argue that time spent teaching equates with scholarship in teaching. ${ }^{2}$

The characteristics which mark scholarly work are evidence, interpretation, and critical appraisal. The last requires that peers review the work, i.e., colleagues who are knowledgeable in the discipline and can make critical comments on content, objectives, and their attainment (Hutchings, 1994). Now, student ratings are the most commonly relied upon and standard method used to assess teaching. On the questionnaires used for this purpose, students are asked if the instructor is organized, accessible outside class, fair, and enthusiastic. None of those questions are designed to reveal if teaching is scholarly.

Shulman (1993) clearly thinks teaching must be reconnected to the disciplines and peers must review teaching. As with research, academics need to create hard evidence of their teaching scholarship. He argues, 
"We do not judge the quality of scholarship on a casual comment made in the hall. We say, 'You must write that up.' We go about making visible the invisible.... If pedagogy is important then we will need to do the same." (p. 7).

\section{Parallels in Research and Teaching}

The idea of teaching as a scholarly pursuit is not new. Dewey (in McEwan \& Bull, 1991) early claimed that mature reflection on teaching shares the same general features as the scientific method because, "They are both acts of inquiry that lead out into an expanding world of subject matter" (p. 331).

At the 11th Annual Conference of the Society for Teaching and Learning in Higher Education (STLHE), Hansen and Roberts (1991) examined the parallels between approaching a typical "research" and a typical "teaching" problem. Their basic model, with some modifications, is presented in Table 1.

The parallels elaborated above reveal that this model of teaching meets scholarship's criteria; the individual is skeptical, gathers evidence, interprets evidence, and makes new ideas accessible to colleagues and students. When this occurs, teaching is available for critique and revision. It, thus, has the collegial nurturing which maintains academic vitality.

Although the model clearly shows the parallels in scholarly research and teaching, it does not represent the vision of teaching held by most academics. Geis and Smith (1979) find faculty members think of teaching as a combination of content knowledge and enthusiasm. When Smith (1995) reminds us that the way we frame a problem influences how we solve it, it is reasonable that faculty assume teaching improves by learning more content not by considering strategies for making the discipline more accessible to students (Gaff, 1975).

\section{The Scholarship of Teaching: A Force Field Analysis}

While all academics must show evidence of continuing scholarship, all may not wish to conduct traditional discipline-based research. Individuals choosing other scholarly pursuits often feel marginalized because few institutions have embraced Boyer's (1990) more comprehensive vision of 
Table 1

\section{Parallels Between Approaching a Typical "Research" and a Typical "Teaching" Problem}

\section{RESEARCH}

\section{Background Scholarship}

- knowledge base

- identification of "problem"

- development of a strategy (hypothesis)

- experimental design

\section{Implementation}

- the "experiment"

\section{$\underline{\text { Effectiveness }}$}

depends on:

- research expertise

- organizational skills

- observational skills

- commitment to research

- attitude to research

- interaction with colleagues (collaboration and criticism)

\section{New Scholarship}

- evaluate results

- plan further "research" for clearer insight

- make ideas available to colleagues

\section{TEACHING}

Background Scholarship

- knowledge base

- identification of "problem"

- development of a strategy (basic plan)

- teaching strategy

Implementation

- the "teaching"

\section{Effectiveness}

depends on:

- research expertise

- organizational skills

- observational skills

- commitment to teaching

- attitude to teaching

- interaction with colleagues (collaboration and criticism)
New Scholarship

- evaluate results

- plan further "strategies" for greater effectiveness

- make ideas available to colleagues 
scholarship. In an attempt to clarify the reasons the academy is not embracing the extended view of scholarship, the authors asked participants at a workshop on the Scholarship of Teaching (Annual Conference of the Society for Teaching and Learning in Higher Education, 1992) what forces work for, and against, the following goal: "Enhancing the recognition and reward for scholarship in teaching within our university community." Their responses in a force field analysis format are given in Table 2.

Many of the same forces were identified as working for and against the goal. We suggest this indicates the participants' ambivalence to change. Factors which influence the seeming paradox will be addressed below.

\section{Making Changes}

Bergquist and Barber (1977) find the negative forces acting on a goal increase as positive forces become more insistent. Consequently, it requires less energy and is more effective to remove or reduce the forces working against the goal than push harder and harder to reach the goal.

Perhaps the first forces to consider are tied to the value system which clearly places disciplinary research first (Fairweather, 1993; Jaspers, 1960; Ladd, 1979; Neatby, 1982; Skolnik \& Rowen, 1984). Changing the university's view of teaching and accepting it as a legitimate form of scholarship requires a major cultural shift. Shulman (1993) knows this and suggests that teaching, like research, must be public. Consequently, academics must remove the forces which maintain teaching's solitude. Only when teaching becomes accessible to the collegial conversations which refine ideas, and the collegial reviews which judge and further sharpen them, will teaching be recognized as serious academic work.

Placing the same forces on both sides of the goal also may reveal a lack of trust. Academic administrators, for example, have been saying for years that they value teaching and that it is taken seriously by Promotion and Tenure Committees. Yet, the data clearly show that teaching is not as well rewarded as research (Fairweather, 1993). When contemplating this reality, we must remember most teaching is not peer reviewed because faculty in general are reluctant to engage in this 


\section{Table 2}

\section{Forces Working For and Against the Goal}

\section{Forces Working FOR the Goal $\leftarrow$}

- Instructional development units, teaching services

- Faculty energy/ideas/creativity

- Activities of The Society for Teaching and Learning in Higher Education

- Professional Associations

- The move to teaching dossiers (to document teaching)

- Independent evaluation/peer review of teaching

- Boyer's Report

- Low faculty morale

- Synergism between teaching and research

- Public pressure

- University mission/goal statements

- Funding (tied to public pressure)

- Support from the private sector

- Students

- Parents

- Deans and Vice-Presidents who are teachers

- Faculty Associations fighting for teaching faculty

- The rise of feminism and feminist pedagogy

\section{$\rightarrow$ Forces Working AGAINST the Goal}

- The actions of Management (lip service but nothing else)

- Boards of Governors

- Rewards primarily for discipline research

- Lack of experience assessing the scholarship of teaching

- The reluctance of faculty to open up their classrooms to colleagues

- Graduate schools that provide no preparation for teaching

- Shortage of journals for exchanges about teaching

- Myths about teaching

- The backlash against the rise of feminism

- The attitudes and influence of senior faculty

- The attitudes of department heads/chairs

- The culture of universities

- The politics of universities

- Lack of portability of teaching

- Inertia

- Competitiveness

- Faculty unions

- Professional Associations

- Low faculty morale 
process. Until it is, academics and academic administrators will be loath to offer it the same stature and rewards as disciplinary research.

What would constitute peer review of teaching? Usually when academics think of reviewing teaching, they think of classroom visitations often by the chair. But, academics do not think they have reviewed a peer's research by observing the individual in his/her lab, archive, or field. Hence, coming into the classroom cannot constitute peer review. Added to the issues surrounding classroom visits are the findings which show colleagues are so generous in their ratings of classroom teaching that their observations are not a reliable source of evidence (March, 1987).

Peers also think they are reviewing teaching when they examine and assess the students' comments and ratings. This, too, does not constitute peer review. Peers need to review the individuals' thinking about their teaching. Ideas must be shaped, sharpened, and argued logically before being reviewed by peers. It is for these reasons Shulman (1993) states, "...artifacts of teaching must be created and preserved so that they can be judged by communities of peers beyond the office next door" (p. 7).

An artifact, thus, could be created as the individual publishes the outcomes of ideas generated through reflective teaching. To accomplish this, faculty must become aware of the journals devoted to university teaching and the kinds of articles such journals accept. Now most faculty members are unfamiliar with the teaching literature and know little of how to publish in it. To assist them, we provide a partial list of journals, both general and specific (Appendix A). Faculty also will want to attend meetings to present and discuss their ideas. We include a selection of colloquia where results can be presented (Appendix B).

Another artifact of teaching is the teaching dossier (Shore et al., 1980), which is gradually being adopted in many Canadian universities. For example, recently the University of Guelph revised article 9.04 (iv) of its policy on Tenure, Promotion and Time and Performance Step Increase Considerations, (University of Guelph, 1995). It now states, "Part of the regular evaluation by the Department Tenure and Promotion Committee will be based on a teaching dossier which provides a vehicle for faculty to report teaching accomplishments." The policy statement expands on the minimal requirements of the dossier by stating, "This dossier will include 
a teaching statement in which the faculty member provides a contextual commentary on teaching experiences and objectives." At McMaster University a new policy (February 9, 1994) calls for assessment of teaching by peers and students. The policy states that "...information and material should be organized into a 'teaching portfolio'...this portfolio should contain whatever information is felt to be relevant to a review of the instructor's teaching and accomplishments...." (p. 2).

Besides the introduction of the teaching dossier, there are other indications that the culture of teaching is changing. Universities are offering courses to graduate students preparing them for a future teaching role. Likewise, programs for new faculty members, now found on most campuses, increase awareness and encourage collegial conversations about teaching.

\section{Canadian Examples of The Scholarship of Teaching}

Boyer's (1990) report lacks the specific examples of scholarship in teaching which Schön (1990) claims are essential for understanding. The work of faculty members who have received Canada's $3 \mathrm{M}$ Teaching Fellowship provide useful illustrations of the scholarship of teaching. The award, sponsored by 3M Canada Inc. and administered by The Society for Teaching and Learning in Higher Education, is awarded to faculty whose teaching is exemplary and who display educational leadership. The criteria for the award are those used to assess scholarship: the faculty member questions, makes interpretations based on evidence, draws conclusions which she or he makes available to colleagues for their critical assessment. The award has been presented annually for the past ten years indicating that scholarly teaching exists and can be identified.

Clearly, an exhaustive list of the $3 \mathrm{M}$ Fellows contributions is beyond the scope of this paper. However, the following selection of examples is provided to indicate how the work of the $3 \mathrm{M}$ Fellows extends the vision of scholarship in teaching.

\section{Research on Teaching}

Nearly $50 \%$ of $3 \mathrm{M}$ Fellows conduct research and publish peer reviewed articles on teaching in higher education. Topics 
include: problem-based learning, problem-solving, teaching communication skills, individualized instruction.

One in ten write/edit/publish newsletters on higher education, e.g., $\mathbf{P}$ (roblem) S(olving) $\mathbf{N}$ (ews) is one with an international circulation. Other newsletters circulate primarily within an institution.

A quarter of the $3 \mathrm{M}$ Fellows present educational findings at national and international conferences. Some typical titles include:

- "Faculty Development in Teaching: Some Experiences, Perspectives, and Blueprints," STLHE (Canada).

- "Improving Teaching by Reflecting on Practice," POD (United States).

- "The North American Approach to Veterinary Medical Education," University of Ghent (Belgium).

In addition, the $3 \mathrm{M}$ Fellows are involved in organizing conferences or symposia on pedagogy in their discipline.

\section{Curriculum Development}

$3 \mathrm{M}$ Fellows talk with colleagues about curricular questions on committees and during workshops, seminars, and symposia. These avenues enable them to break the silence which surrounds teaching (Weimer, 1987; Gaff, 1975). Often the discussions result in significant curricular changes, e.g., Critical Thinking Across the Curriculum, Computers Across the Curriculum, Women's Studies.

\section{Course Materials}

The $3 \mathrm{M}$ Fellows write textbooks, course manuals, develop videos, and create software. The high quality of this work (as determined by peers) means that these resources are often adopted by other departments and institutions.

\section{Faculty Development}

Nearly all of the $3 \mathrm{M}$ Fellows offer leadership in campuswide faculty development programs by conducting collegial 
consultations, offering workshops for colleagues at their own institutions, and at institutions across Canada and abroad - Australia, Germany, Malaysia, China, and the United Kingdom.

\section{Institutional Development}

Nearly one-third of the $3 \mathrm{M}$ Fellows play pivotal roles in changing the culture of teaching and learning at their institutions by developing documents on topics like "Teaching Writing" (York University), "The Evaluation of Teaching and Courses" (University of Ottawa), and "Learning Objectives" (University of Guelph). Realizing that documents alone do not produce change, the $3 \mathrm{M}$ Fellows create pilot projects which demonstrate the innovation's viability and discuss the reports and innovations with colleagues in open meetings, seminars, and workshops.

\section{Teaching Students}

The $3 \mathrm{M}$ Fellows continually question what they teach and how they teach. For example, McMaster's Don Woods (1991) says, "I spent the first 15 years of my life as a teacher trying to show students how I solve problems and hoped, like having someone watch a violinist perform, that the 'watchers' would become skilled problem solvers (or in the analogy, skilled violinists). They don't.... We found we have to identify explicitly one particular skill, give the students a chance to see how they do it, offer a model of how the skills should be done and then give them a chance - with immediate feedback - to improve" (p. 8).

The University of Western Ontario's Madeline Lennon (1993) found her classes grew from 65 to 330 students. She says, "Over the years, I have learned about some very helpful techniques that allow me to actively address the frustrations I experience around the issue of how to involve students more effectively in the learning process" (p. 5).

Guelph's Sandy Middleton (1994) has completely revamped an introductory course in Zoology because he realized that the classical 
approach with its emphasis on taxonomy and anatomy did not reflect the dynamic, conceptual nature of the discipline. The course, in its new format, focuses on Zoology as a branch of science in which the concepts and methods of investigation are given prominence. Questions are raised to which the students must find the answer either through devising and testing hypotheses, or through observation and synthesis. Creative thinking replaces rote learning.

\section{A Policy Which Supports Diversity in Scholarship}

Although external awards for teaching scholarship, like the $3 \mathrm{M}$ Fellowships, recognize and celebrate teaching excellence, the institutions themselves must value, encourage, and reward scholarly teaching. The University of Guelph ${ }^{3}$ has a policy, developed in 1983, which encourages scholarly diversity amongst its faculty. Although the policy is not perfect, and certainly not the only one of its kind, it is one with which the authors are familiar.

The policy, Article 19, was revised in the Special Plan Agreement ${ }^{4}$ (University of Guelph, 1993). It states:

"...the University should accommodate a large diversity of acceptable paths for career development.... Career paths may give particular emphasis to discipline-based research, education, extension, or similar activities.... Each career path must leave open the possibility of promotion to the highest academic ranks and no path is to be deemed as inferior to any other."

The document further states, "...every faculty member must have a teaching/education component of responsibility." The policy definitely states that, when teaching is the career emphasis, the individual is:

"...expected to engage in scholarly activity which may be related to education. Such activity should have impact and influence beyond the University of Guelph. That is, classroom instruction, by itself, only partially fulfills the responsibilities of a faculty member whose career path emphasizes teaching/education" (pp. 27-28). ${ }^{5}$

Diversity is further legitimized by the University of Guelph's definition of research: "The term research as here used means the search for new 
knowledge, the conscious effort to add directly to the store of knowledge or to alter ways in which we see, appraise, or apply what is already known" (University of Guelph, 1989, p. A-1).

To date few faculty have chosen to emphasize the teaching career path. The University of Guelph's experience reveals, among other things, the importance of language. Faculty tend to interpret the requirement to engage in "a scholarly activity which may be related to education" to mean conducting research in the field of education. Thinking that would mean switching disciplines, they refrain from choosing the teaching career path. They also are apprehensive over the designation of the teaching career path as the "alternate career path." In the eyes of many, that designation is seen as being a secondary choice and, hence, of lesser value than the traditional research path.

Guelph's experience does reveal that a university-wide policy with flexible career options is a necessary, but not sufficient, condition to validate scholarly diversity. Because career decisions are made first at the departmental level, policies like Article 19 also must become a part of departmental policy.

Policies, once in place, must be rigorously implemented. As a critical mass of faculty choose to emphasize the scholarship of teaching, and are recognized for their work, universities can be assured their policies are effective. It would appear from the current situation that much work remains.

\section{How will the scholarship of teaching foster better education?}

If scholarly teaching is to develop, academics must address teaching questions and make their findings accessible to colleagues. As Medley (1987) reminds us, university teaching is at the same developmental stage as medicine was at the turn of the century when doctors were guided by case knowledge developed through practice. Happily most patients improved so the doctors came to trust their treatments.

Academics develop case knowledge as they teach. Happily most students learn. Still, if results were studied more closely and new ways were sought to help students learn, teaching could become more effective. It is not enough to leave this work to those in the field of education because 
asking questions about teaching requires "...deep, expert knowledge of specific subject matter" (AAC, 1985, p. 2). As academics open their teaching reflections to collegial discussion (and to the refinements which follow), their understanding of teaching will deepen, teaching will improve, and the universities' critics will be silenced.

\section{Conclusions}

If teaching is to be valued, it must be considered legitimate academic work. The scholarship of teaching, because it extends the definition of the university and makes it more viable, meets Bennis's (1970) criteria for effective change.

Extending the definition of scholarship not only makes a cultural shift possible, it has the added advantage of offering all academics greater knowledge of their disciplines. Like the astronauts and engineers in The Right Stuff (Woolf, 1979) academics like to push the envelope. By reminding us that, like an envelope, knowledge has four sides, application, integration, discovery, and teaching, Boyer (1990) suggests fresh possibilities for extending knowledge. This more encompassing vision of knowledge gives academics opportunities to understand how their disciplines are taught, applied, integrated, as well as discovered. These multiple ways of knowing create fresh approaches for academics to explore and more deeply engage their disciplines.

\section{References}

American Association for Higher Education. (1992, April 5-8). Forum on Exemplary Teaching. Chicago, IL.

Association of American Colleges. (1985). Integrity in the college curriculum:

A report to the academic community. Washington, DC.

Bennis, W. (1970). Who sank the yellow submarine? In W. Bennis, K. Benne,

R. Chin, \& K. Corey (Eds.), The planning of change (pp. 219-227). New York, NY: Holt Reinhart and Winston.

Bergquist, W.H., \& Barber, N. (1977). Building a project. In W. Bergquist,

S. Phillips, \& G. Quehl (Eds.), A handbook for faculty development, Vol. 2 (p. 256). Washington, DC: Council for the Advancement of Small Colleges. 
Bok, D. (1992). Reclaiming the public trust. Change, 24(4), 13-19.

Braxton, J. (1991). The influence of graduate department quality on the sanctioning of scientific misconduct. Journal of Higher Education, 62(1), 87-108.

Boyer, E. (1990). Scholarship reconsidered. Princeton, NJ: The Carnegie Foundation for the Advancement of Teaching.

Cashin, W., \& Clegg, V. (1994). Periodicals related to college teaching. Idea Paper, No. 28. Manhattan, KS: Kansas State University.

Cerbin, W. (1993). Fostering a culture of teaching as scholarship. The Teaching Professor, 1(2).

Fairweather, J. (1993). Teaching, research, and faculty rewards. University Park, PA: The Pennsylvania State University, National Center on Postsecondary Teaching, Learning, and Assessment.

Gaff. J. (1975). Toward faculty renewal. San Francisco, CA: Jossey-Bass.

Geis, G., \& Smith, R. (1979). Professors' perceptions of teaching and learning:

Implications for faculty development. Paper presented at the American Educational Research Association, San Francisco, CA.

Hansen, P., \& Roberts, K.B. (1991). Understanding scholarship: Expanding its meaning and practice in teaching. Paper presented at the 11 th Annual Conference on Teaching and Learning in Higher Education, Halifax, NS.

Hutchings, P. (1994). Peer review of teaching. AAHE Bulletin, 47(3), 3-7. Jaspers, K. (1960). The idea of the university. London, GB: Peter Owen.

Ladd, E.C. Jr. (1979). The work experience of American college professors: Some data on an argument. Current Issues in Higher Education, 2, 3-12.

Lennon, M. (1993). Delights of teaching and the large class. Teaching Forum, 44. University of Guelph, Guelph, ON.

Lynton, E. (1993). Rethinking what it means to be a scholar: Where do we go from here? Paper presented at AAHE: Faculty Roles and Rewards Conference, San Antonio, TX.

McMaster University. (1994). University policy on the encouragement of teaching excellence. Hamilton, $\mathrm{ON}$.

Marsh, H.W. (1987). Students evaluations of teaching. In M. Dunkin (Ed.). The international encyclopedia of teaching and teacher education (pp. 181187). Oxford, GB: Pergamon Press.

McEwan, H., \& Bull, B. (1991). The pedagogic nature of subject matter knowledge. American Educational Research Journal, 28, 316-334.

Medley, D.M. (1987). Evolution of research on teaching. In M. Dunkin (Ed.), The international encyclopedia of teaching and teacher education (pp. 105113). Oxford, GB: Pergamon Press. 
Middleton, A.L.A. (1994). The two classroom cultures: How can we bridge the gap? Paper presented at the 14th annual STLHE Conference, Simon Fraser University, Vancouver, BC.

Neatby, J.B. (1982). The gospel of research: The transformation of English-Canadian universities. Transactions of the Royal Society of Canada, 20(4), 275-284.

Rice, E. (1992). Toward a broader conception of scholarship: The American context. In T. Whiston, \& R. Geiger (Eds.), Research and Higher Education: The United Kingdom and the United States (pp. 117-129). Buckingham, GB: The Society for Research into Higher Education and Open University Press.

Schön, D. (1990). Knowing, scholarship, and faculty rewards: The new American scholar in theory and practice. Talk given at AAHE, San Francisco, CA.

Shore, B.M., Foster, S.F., Knapper, C.K., Nadeau, G.G., Neill, N., \& Sim, S.W. (1980). The teaching dossier: $A$ guide to its preparation and use. Canadian Association of University Teachers, Ottawa, ON.

Shulman, L. (1993). Teaching as community property. Change, 25(6), 6-7.

Skolnik, M., \& Rowan, N. (1984). Please sir, I want some more. Toronto, ON: Ontario Institute for Studies in Education Press.

Smith, R. (1995). Reflecting critically on our efforts to improve instruction. In To improve the academy (in press). Stillwater, OK: New Forums Press Inc.

Smith, S. (1991). Commission of inquiry on Canadian university education. Ottawa, ON: Association of Universities and Colleges of Canada.

University of Guelph. (1989 rev.). Research policies handbook (Section A). Guelph, ON.

University of Guelph. (1993). Special plan agreement. Faculty handbook, (pp. 28-29). Guelph, ON.

University of Guelph. (1995). Policy with respect to information for tenure, promotion and TSPI considerations (Section LX, Item 9.04). Guelph, ON

Weimer, M. (1987). Conversing with a colleague. The Teaching Professor, $1(5), 1-2$.

Woolf, T. (1979). The right stuff. New York, NY: Farrar, Straus \& Giroux, Inc. Woods, D. (1991). Ten ideas about managing the learning environment. Teaching Forum, 41, University of Guelph, Guelph, ON. 


\section{Appendix A}

\section{Where to publish the Scholarship of Teaching: A Partial List}

\section{General Journals in Higher Education}

Academe (American Association of University Professors)

Canadian Journal of Higher Education

Change Magazine of Higher Learning (AAHE)

Chronicle of Higher Education (weekly)

Community College Review

College Teaching

Educational Record

HERDSA (Higher Education Research and Development Society of Australasia) News

Higher Education

Higher Education Research and Development

Journal of Higher Education

Liberal Education (Association of American Colleges Bulletin)

New Directions for Teaching and Learning

Research in Higher Education

Review of Higher Education

The Times Higher Education Supplement

The Teaching Professor

To Improve the Academy

\section{Discipline Specific}

\section{Agriculture}

Journal of Natural Resources and Life Sciences Education

Biology

American Biology Teacher

Journal of Biological Education

Business

Journal of Business Education

Chemistry

Education in Chemistry

Journal of Chemical Education

Biochemical Education 
Computer Science

SIGCSE Education

Economics

Journal of Economic Education

Engineering

Chemical Engineering Education

American Society of Engineering Education

English

ADE Bulletin

College Composition and Communication

College English

Freshman English News

JETT: Journal of English Teaching Techniques

Research in the Teaching of English

English as a Second Language

Teachers of English to Speakers of Other Languages

TESL Talk

Geography

Journal of Geography

History

History Teaching

Languages and Literatures and Linguistics

ADFL Bulletin

Foreign Language Annals

IRAL: International Review of Applied Linguistics in Language Teaching

Language Learning

Teaching Language Through Literature

Law

Journal of Legal Education

Liberal Arts/General Education

Forum for Liberal Education

Liberal Education

Mathematics

Journal for Research in Mathematics

The Journal of Undergraduate Mathematics and Its Applications (UMAP)

The American Mathematics Monthly

Mathematics Magazine

The College Mathematics Journal 
Music

Journal of Research in Music Education

Music Educators Journal

Philosophy

Teaching Philosophy

Physics

Physics Education

Physics Teacher

Physics Today

Political Science

Teaching Political Science

Psychology

Teaching of Psychology

Science

European Journal of Science Education

Journal of College Science Teaching

Journal of Research in Science Teaching

Social Work

Canadian Journal of Social Work Education

Journal of Education for Social Work

Sociology

ASA Teaching Newsletter

Teaching Sociology

Teacher Education

Australian Journal of Teacher Education

Journal of Education for Teaching

Journal of Teacher Education

Cashin and Clegg (1994) developed a list of American periodicals on teaching and published it in the Center for Faculty Evaluation and Development's Idea Paper, No. 28, Periodicals Related to College Teaching. The Center's address is Kansas State University, College Court Building, Manhattan, KS 66506-6001. 


\section{Appendix B}

Where to present the Scholarship of Teaching: A Partial List

\section{General Conferences}

The Society for Teaching and Learning in Higher Education: Annual Conference each June; Location varies around Canada; For more information contact:

Pat Lockhart

Instructional Development Centre

General Sciences Building, Room 217

McMaster University

1280 Main Street W.

Hamilton, ON

Canada

L8S $4 \mathrm{~K} 1$

The Higher Education, Research and Development Society of Australasia HERDSA Membership

c/o PBOBLARC

PO Box 555

Campbellton, NSW, 2560

Australia

Professional and Organizational Development (POD) Network

c/o David Graf

15B Exhibit Hall South

Iowa State University

Ames, IA 50011

U.S.A.

American Association for Higher Education (AAHE)

One Dupont Circle, Suite 360

Washington, DC 20036-1110

U.S.A.

telephone - 202-293-6440

fax - 202-293-0073 
Improving University Teaching

University of Maryland University College

University Boulevard at Adelphi Road

College Park, MD 20742-1659

U.S.A.

\section{Discipline Specific}

Within discipline conferences like the American Society of Agronomy, there are special sessions on teaching. Disciplines also have conferences specifically devoted to teaching.

\section{Notes}

1 At the American Association of Higher Education's (AAHE) 1992 Forum of Exemplary Teaching, a disgruntled faculty member remarked that engaging in the scholarship of teaching looked like another way to increase each academic's work load.

2 Boyer (1990) unfortunately confuses the relationship of time and scholarship when he states, "At the very heart of the current debate [about the priority of teaching]...is the issue of faculty time" (p.xi).

3 The University of Guelph, one of the 16 universities in Ontario, has 760 faculty, 11,000 full-time and 2,000 part-time undergraduates, and 1,500 graduate students (Masters and Ph.D.).

4 Guelph faculty are not unionized.

5 This proviso in the Agreement agrees well with the requirement that scholarship is public. 